\title{
Reducing body myopathy
}

INSERM

\section{Source}

INSERM. (1999). Orphanet: an online rare disease and orphan drug data base. Reducing body myopathy. ORPHA:97239

Reducing body myopathy (RBM) is a rare muscle disorder marked by progressive muscle weakness and the presence of characteristic inclusion bodies in affected muscle fibres. 